RJPSS Sept. 2020 Vol. XLV No.2, ISSN: (P)0258-1701 (e)2454-3403 Impact Factor: 7.717

https://doi.org/10.31995/rjpss.2020.v45i01.033

\title{
Case Study of Primary and Secondary Waste Management Systems in Saharanpur City
}

\author{
Arvind Kumar Arora \\ School of Agriculture \& Environmental Sciences, \\ Shobhit University, Gangoh, Saharanpur \\ Email: arvindarora.sre@gmail.com \\ Dr. N.C. Mishra \\ Associate Prof., Dept. of Polymer and Process Engineering, IIT, Roorkee \\ Dr. Mohd. Vasseem \\ Asst. Prof., School of Agriculture \& Environmental Sciences, \\ Shobhit University, Gangoh, Saharanpur
}

Abstract

For a rapidly developing country like India, it is highly important for the authorities to systematically manage cities and towns. Saharanpur, in the state of Uttar Pradesh, is one such city that is needed for improvement in planning and management. Being a densely populated city, Saharanpur also produces a large number of wastes that need to be disposed of/ treated. For this, it is important to understand the composition and characteristics of the waste. This paper presents a case study conducted in order to perform qualitative and quantitative analysis of waste produced in Saharanpur city.

Keywords: primary waste management, secondary waste management, stratification, Saharanpur, waste sampling, and characterization.
Reference to this paper

should be made as follows:

Received: 01.08.2020

Approved: 30.09 .2020

Arvind Kumar Arora

Dr. N.C. Mishra

Dr. Mohd. Vasseem

Case Study of Primary and Secondary Waste

Management Systems in

Saharanpur City

Article No. 33

RJPSS Sept. 2020,

Vol. XLV No. 2,

pp. 275-287

Online available at:

https://anubooks.com/ ripss-2020-vol-xlv-no-2/

https://doi.org/10.31995/ rjpss.2020.v45i01.033 
Case Study of Primary and Secondary Waste Management Systems in Saharanpur City

Arvind Kumar Arora, Dr. N.C. Mishra, Dr. Mohd. Vasseem

\section{Introduction:}

Solid Waste Management [1] SMW is an integral part of the urban environment and planning of the urban infrastructure to enforce a safe and healthy human environment while considering the promotion of sustainable economic growth. Afraid economic growth by the industrialization of the developing countries in the world has created serious problems of waste disposal due to uncontrolled and un-monitored urbanization. The problem is further aggravated by the lack of financial as well as human resources trained in solid waste management practice in the sphere of collection, transportation, processing, and final disposal, whereas aspects like recycle, reuse and recovery of the solid waste in grossly demand and supply-driven or disorganized in most cases, in this scenario, the responsible person or agencies concerned with the public health and environment protection face the crisis of ineffective solid waste management.

A scientifically designed solid waste management system and related sewer system of Saharanpur, including improved methods of collection and transportation, recycling, etc is the need with respect to the environment and good urban planning for good living aspects. The first step for planning such a system is to understand the requirements. For this, the responsible city authorities need the knowledge regarding the different kinds of wastes being generated in different regions of the city. However, it has been found that there has not been any survey or study conducted in this field in the past. Therefore, this work is focused on investigating the wastes generated in Saharanpur city by conducting a survey in different localities of the city.

This paper is organized in different sections that provide a description of the methodology and approach used for selecting the survey sample, followed by a description of the aspects of waste under investigation, mainly, quantitative and qualitative characteristics. Following this, the results of the survey and other observations are presented and the paper is closed with a short conclusion.

\section{Methodology of Waste Quantification:}

The information on the quantity of waste generated and its composition is the basic need for planning the SWM system. For these, respondents were provided with waste collection bags to the waste generator like residential areas and asked to collect to store all the waste generated for a 20 -hour cycle. In the case of SNN, the total waste generated for a 24-hour cycle was accumulated in a designated area and subsequently collected by the responded the next morning. After the spatial distribution, sampling was done for different areas, sampling was further done 
RJPSS Sept. 2020 Vol. XLV No.2, ISSN: (P)0258-1701 (e)2454-3403 Impact Factor: 7.717

https://doi.org/10.31995/rjpss.2020.v45i01.033

category of generators such as residential, commercial, institutional, market, slum, etc., for the residential area, sampling was further done to represent the general household and slum areas.

\section{Adopted strategy for sampling}

The adopted methodology of sampling involves the collection of representative samples of SWM fraction to determine the composition and characterization of waste, the sampling and analysis will be conducted by following the analysis design and planning through the following steps.

- Pre-investigation

- Analysis Design \&Planning

- Execution of waste analysis

- Evaluation of waste analysis

\section{Stratification}

Stratification is the statistical subdivision of the homogenous parent population (i.e. Waste generation over an area) into homogenous subpopulations called strata. Stratification strategy was followed to finalize the location and number of samples of the study area i.e., this methodology is helpful to increase the accuracy of the waste analysis results.

\section{Analysis Design andPlanning:}

The design plan comprises the type of sampling, number \& type of standard level of sampling. The identification of sampling locations will be made by conducting field visits and investigation of the waste generators from different streams. The random sampling of waste will be finalized by considering the variation coefficient of approx. $45 \%$ and by providing a maximum allowance of $10 \%$ as a random sampling error. The variation coefficient is generally considered based on previous waste analysis reports in the study area. However, in this case,duetoabsenceofpreviouswasteanalysisreports,variationcoefficienthasbeenassumedtobe $45 \%$. The required number of samples has been determined by using the following equation.

$$
\begin{aligned}
\mathrm{n}= & \left(\frac{t_{\alpha ; n-1} * \operatorname{var} \operatorname{coeff}(X i)}{\varepsilon}\right)^{2} \\
& =((1.96 * 45) /(10))^{2} \\
& =77.79(\text { approx. } 78)
\end{aligned}
$$

$\mathrm{n}=$ Necessary number of sampling units; $\operatorname{varcoeff}(X i)=$ Natural Variation Coefficient $=45 \%$ (assumed); $t_{a, n-1}=$ 
Case Study of Primary and Secondary Waste Management Systems in Saharanpur City

Arvind Kumar Arora, Dr. N.C. Mishra, Dr. Mohd. Vasseem

Confidence Coefficient $=1.96$ (error

probability of5\%)

$[=$ Random sampling error $=10 \%$

(assumed)

$X i=$ Individual results from previous waste analysis studies (if available)

Table 1: Calculation of the necessary number of sampling units (95\% Confidence Level) [2]

\begin{tabular}{|c|c|c|c|c|c|c|c|c|}
\hline $\begin{array}{l}\text { Natural Variation } \\
\text { coefficient (Gauge } \\
\text { for variation in } \\
\text { parent population) }\end{array}$ & \multicolumn{5}{|c|}{$\begin{array}{l}\text { Sampling Units, } \mathrm{n} \text { (95\%confidence Level) } \\
\text { allowance for random sampling error }(\%)\end{array}$} & ith & nun & \\
\hline (\%) & 2.5 & 5 & & & 15 & & & 25 \\
\hline 20 & 246 & 61 & 15 & 7 & & 4 & 2 & \\
\hline 30 & 553 & 138 & 35 & 15 & & 9 & 6 & \\
\hline 40 & 983 & 246 & 61 & 27 & & 15 & 1 & \\
\hline 50 & 1537 & 384 & 96 & 43 & & 24 & 15 & \\
\hline 60 & 2213 & 553 & 138 & 61 & & 35 & 22 & \\
\hline 70 & 3012 & 753 & 188 & 84 & & 47 & 3 & \\
\hline 80 & 3934 & 983 & 246 & 109 & & 61 & 3 & \\
\hline 90 & 4979 & 1245 & 311 & 138 & & 78 & 5 & \\
\hline 100 & 6147 & 1537 & 384 & 171 & & 96 & 6 & \\
\hline
\end{tabular}

\section{Area Under Investigation:}

The study area i.e., Saharanpur cluster comprises of 16 ULBs covering an area of $3698 \mathrm{sq}$. km. Saharanpur District has 5 Tehsils, namely, Behat, Saharanpur, Naked, Rampur Maniharan, and Deo Band. The region is further divided into 11 Blocks: Sadauli Kadeem, Muzaffarabad, Puwarika, Ballia Kheri, Deoband, Sarsawan, Nagal, Nanuta, Naked, Gangoh \& Rampur Maniharan.

The study area has been divided into four zones based on the location map as shown in Figure 1 Dara Kotatala Swad Bairun, Gopal Nagar, Chakahateti, Garhi Maluk, Kishanpura, Daramilkana, Beri Bag, Jawahar Park, New Madhonagar, Khanalampura, Numaish Camp, Chhipiyan, Mohit Vihar, Khalapar, Kila Nawab Ganj, Nur Basti and, Matiya Mahal has been considered as Zone1. Whereas Vardhman colony, Jatav Nagar, Municipal colony, Madan puri, Sarai Hisamuddin, Siraj colony, Kutubsher, Mubarik Shah, Rani Bazar, Pratap Nagar, Sarai Mardan ali, Dinanath, Hayat colony, Azad colony, Yahiya shah, Sawari bagh, 
https://doi.org/10.31995/rjpss.2020.v45i01.033

Wood seasoning plant, Kamala colony, Nadeem Colony, Daraali bairun, Aali Saharan, Lohani Sarai, Kaji lakkhi gate has been considered as the Zone 2. Mohammadpur page, Bhojpuri, gwalira, fatepur jat, khalasi line, Sharda Nagar, railway quarter, labor colony, Navin Nagar, ITC khalasi line Manak may utter, Manak may Dakshin, gurudwara road, Chandra Nagar has been considered as Zone 3. Mouajjampura, pijaura Badshah Pur, mawikala, Janakpuri, himmat Nagar, Govind Nagar, khanalampura takiya, ilahipura, Gil colony, Hasan Pur Kadeem, Najirpur, Awas Vikas, hakikat Nagar, Sadak dhundli has been considered as Zone 4.

\section{Figure 1: Location Map of the SAHARANPUR}

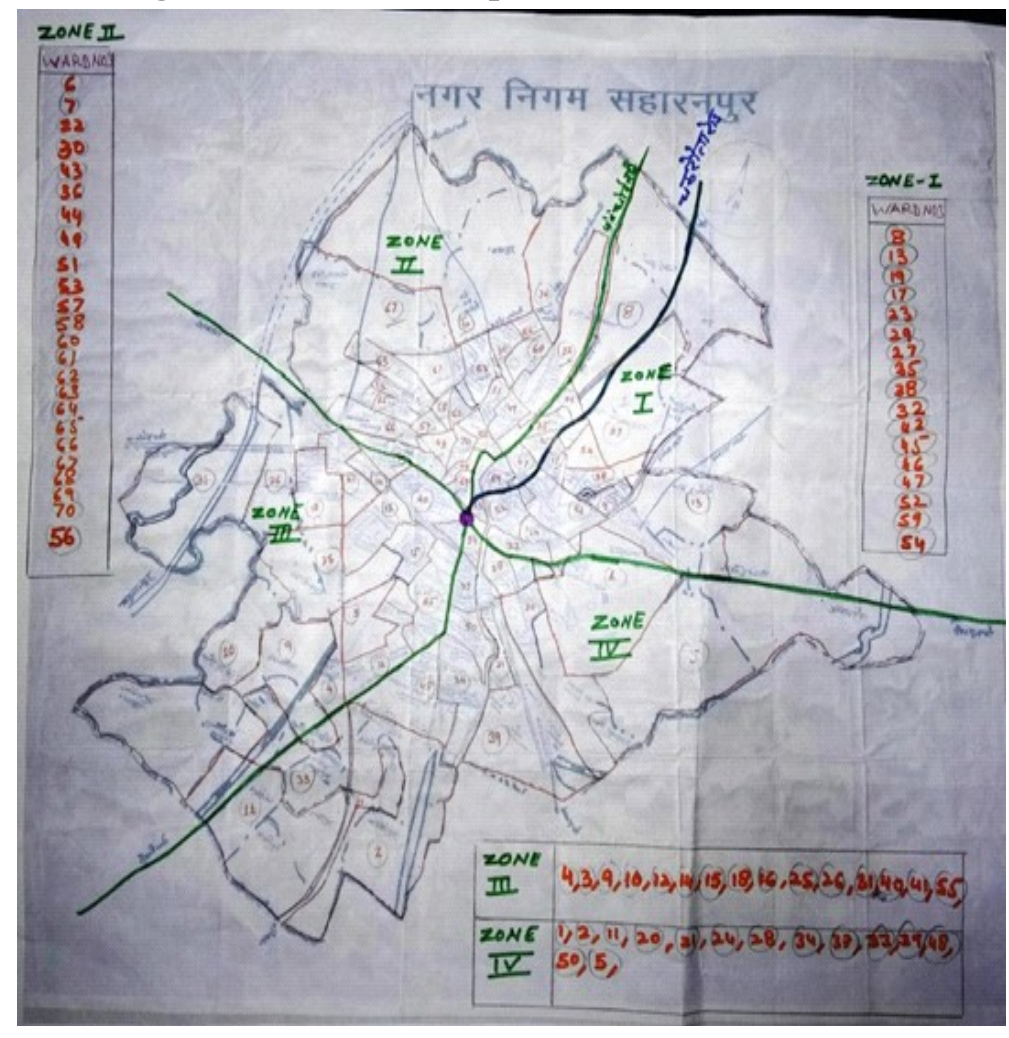

The survey was conducted for a period of three (3) to five (5) consecutive days at selected residential areas representing general households and slum areas of the towns and at bulk waste generating sources such as all major markets, institutions, and at major commercial establishments. Table 2 provides a brief overview of the zones depicted in Figure 1. 
Case Study of Primary and Secondary Waste Management Systems in Saharanpur City

Arvind Kumar Arora, Dr. N.C. Mishra, Dr. Mohd. Vasseem

Table 2: Total Number of Sample Taken for Waste Analysis from different zones

\begin{tabular}{|l|l|l|l|l|l|l|l|}
\hline & \multirow{2}{*}{$\begin{array}{l}\text { Population } \\
\text { of 2017 }\end{array}$} & $\begin{array}{l}\text { Residential } \\
\text { Non-slum }\end{array}$ & $\begin{array}{l}\text { Residential } \\
\text { Slum }\end{array}$ & Commercial & Institutional & Market & Total \\
\hline ZONE 1 & 171772 & 18 & 18 & 18 & 18 & 9 & 81 \\
\hline ZONE 2 & 150824 & 24 & 24 & 24 & 24 & 12 & 108 \\
\hline
\end{tabular}

Table 3: Waste Sampling Result at Saharanpur

\begin{tabular}{|c|c|c|c|c|c|c|c|}
\hline \multirow{2}{*}{$\begin{array}{l}\text { Ward } \\
\text { No. }\end{array}$} & \multirow{2}{*}{$\begin{array}{l}\text { Samples } \\
\text { Collected } \\
\text { From }\end{array}$} & \multirow[t]{2}{*}{$\begin{array}{l}\text { family } \\
\text { members }\end{array}$} & \multicolumn{4}{|c|}{$\begin{array}{c}\text { Date of Sample Collection in } \\
\text { March } 2017\end{array}$} & \multirow[t]{2}{*}{$\begin{array}{l}\text { Total } \\
\text { Samples }\end{array}$} \\
\hline & & & 7 th & 8 th & 9th & 10th & \\
\hline 2 & $\begin{array}{l}\text { Residential - } \\
\text { Non-Slum }\end{array}$ & 5 & 0.625 & 0.595 & 1.70 & 0.465 & \multirow{9}{*}{36} \\
\hline 4 & $\begin{array}{l}\text { Residential - } \\
\text { Non-Slum }\end{array}$ & 6 & 0.49 & 0.225 & 0.34 & 0.42 & \\
\hline 1 & $\begin{array}{l}\text { Residential - } \\
\text { Slum }\end{array}$ & 5 & 0.51 & 2.34 & 0.32 & 0.94 & \\
\hline 10 & $\begin{array}{l}\text { Residential - } \\
\text { Slum }\end{array}$ & 4 & 0.46 & 0.28 & 1.9 & 0.45 & \\
\hline 4 & Commercial* & 5 & 0.74 & 0.275 & 0.81 & 0.865 & \\
\hline 5 & Commercial* & 6 & 0.63 & 0.265 & 0.4 & 0.11 & \\
\hline 9 & Institutional* & 5 & 0.87 & 0.51 & 0.41 & 1.674 & \\
\hline $\begin{array}{l}2 \\
1\end{array}$ & Institutional* & 4 & 2.66 & 0.99 & 0.97 & 0.745 & \\
\hline $\begin{array}{l}2 \\
2\end{array}$ & Market* & & 2.26 & 2.72 & 2.165 & 1.335 & \\
\hline
\end{tabular}

For the household level survey, differentiation of ULBs based on their economic profile (i.e. low-income group, middle-income group, and high-income group) is possible as the entire study area comprises a similar level of services and infrastructure. To further validate the estimates, there is a study to determine the quantity of waste generated by households and shops, etc., in the city in three different economical and geographical areas. This was done by collecting 25 samples of waste from 100 units from 4 different categories for three consecutive days.

\section{Waste Quantifications:}

The information on the number of wastes generated is the basic need for the planning of a solid waste management system. The qualitative and quantitative 
RJPSS Sept. 2020 Vol. XLV No.2, ISSN: (P)0258-1701 (e)2454-3403 Impact Factor: 7.717

https://doi.org/10.31995/rjpss.2020.v45i01.033

assessment for solid waste is carried out at all the major sources of generation. The sampling and analysis methodology were adopted as per CPHEEO Manual, 2016 [3].

For an estimate of the municipal solid waste generated in the town area, a3days detailed sampling for different types of waste generators representing general households and slum population of the town, at bulk waste generating sources such as all major vegetable markets, institutions and at major commercial establishments such as hotel and restaurants/ eateries, etc. have been conducted

\section{Primary waste quantification: residential area}

Primarywastequantificationsurveyforresidentialareawascarriedoutincaseofhouseholds. The average per capita calculations from the survey at the residential area have been calculated at randomly selected wards. The 4 houses in random wards have been identified based on residential non-slum and residential slum group of people. Thesurveywascarriedoutfor4dayscontinuouslyintheselectedhouses.

Table 4: Primary Waste Quantification at Household Level

\begin{tabular}{|c|c|c|c|c|c|c|c|}
\hline \multirow{2}{*}{$\begin{array}{l}\text { S1. } \\
\text { No. }\end{array}$} & \multirow[t]{2}{*}{ Origin } & \multirow[t]{2}{*}{$\begin{array}{l}\text { Family } \\
\text { Members }\end{array}$} & \multicolumn{4}{|c|}{ Date of Sample Collection in March } & \multirow{2}{*}{$\begin{array}{l}\text { AverageWaste } \\
\text { generation } \\
(\mathrm{kg} / \text { capita/day) }\end{array}$} \\
\hline & & & $7^{\text {th }}$ & $8^{\text {th }}$ & $9^{\text {th }}$ & $10^{\text {th }}$ & \\
\hline 1 & \multirow{2}{*}{$\begin{array}{l}\text { Residential } \\
\text { - Non-Slum }\end{array}$} & 5 & 0.625 & 0.595 & 1.700 & 0.465 & 0.169 \\
\hline 2 & & 6 & 0.490 & 1.125 & 0.340 & 0.610 & 0.107 \\
\hline 3 & \multirow{2}{*}{$\begin{array}{l}\text { Residential } \\
\text { - Slum }\end{array}$} & 5 & 0.510 & 2.340 & 0.320 & 0.940 & 0.206 \\
\hline 4 & & 4 & 0.460 & 0.280 & 1.900 & 0.450 & 0.193 \\
\hline
\end{tabular}

Source: Survey

Above table indicates that the average per capita waste generation forSNN area is $169 \mathrm{gm} / \mathrm{capita} /$ day. There were no marked variations observed in the slum and non-slum households. Based upon the waste generationfactorandthepopulationofyear2017, theoverallwastequantificationinNagarNigamhasbeen carried out and presented below in Figure 2.

\section{Primary waste quantification: Institutions}

Primary survey based on visual observation and discussion with the authorities was done to estimate the quantum of waste from various institutions. Primary survey and field investigations reveal that for primary, secondary, and higher secondary schools in the region, the waste generation factor varies.

\section{Waste quantification Summary}

The Summary of primary waste quantification results is depicted below. 
Case Study of Primary and Secondary Waste Management Systems in Saharanpur City

Arvind Kumar Arora, Dr. N.C. Mishra, Dr. Mohd. Vasseem

\begin{tabular}{|l|l|l|}
\hline S1. No. & $\begin{array}{l}\text { Des } \\
\text { cript } \\
\text { ion }\end{array}$ & Quantity (TPD) \\
\hline 1 & Residential household & 43.16 \\
\hline 2 & Market area & 9.5 \\
\hline 3 & Commercial Establishments & 14.75 \\
\hline 4 & Hotels/ Eateries/Restaurant & 6.5 \\
\hline Total & \multicolumn{2}{|l}{} \\
\hline
\end{tabular}

Figure 2: Comparative Waste Generation (Residential) at Saharanpur

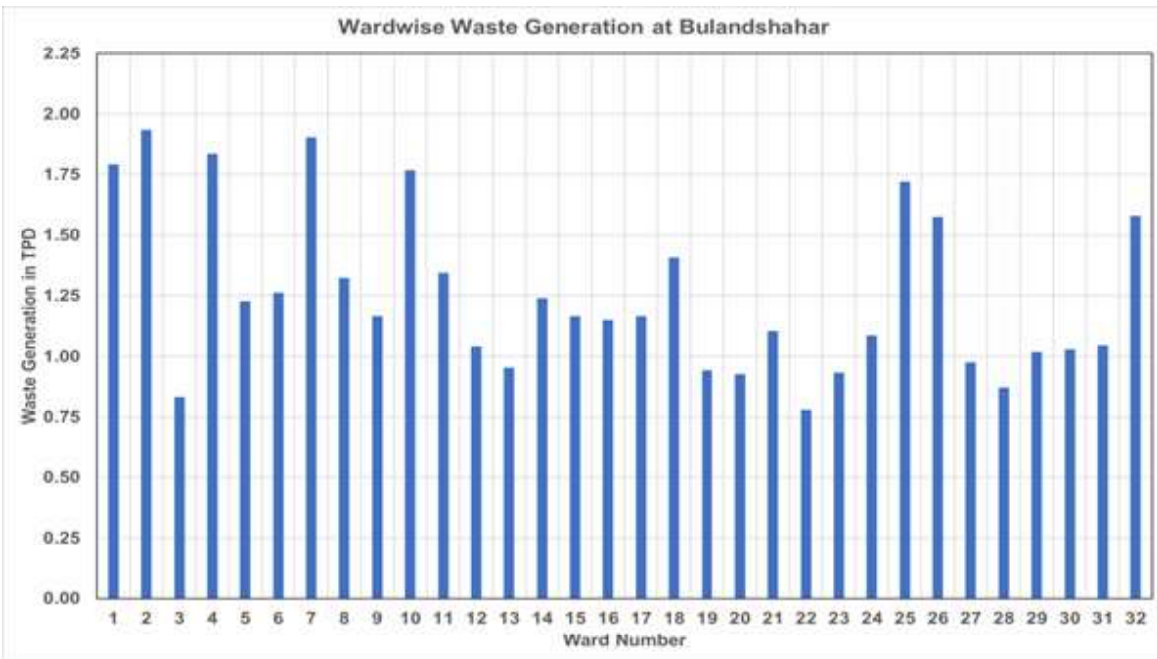

\section{Waste Projections}

To project the future waste quantity to be generated in next 20 years, projected waste generation factor and projected population have been considered. For calculation of future waste generation, the current waste generation factor of $304 \mathrm{gm} /$ capita/day has been projected at the rate of $1.3 \%$ per annum.

\section{Waste Characterization:}

As discussed earlier, the sources of waste generation are residential, commercial, markets, etc. within the study area. These are further classified based on their composition, characteristics, physical and chemical characteristics as biodegradable, recyclables, combustibles, etc. For an effective SWM, it is important to investigate the properties of waste apart from their origin.

\section{Sample Size and Location of Sampling}


RJPSS Sept. 2020 Vol. XLV No.2, ISSN: (P)0258-1701 (e)2454-3403 Impact Factor: 7.717

https://doi.org/10.31995/rjpss.2020.v45i01.033

The selection of sample size and the sampling locations have been done through professional judgment and in consultation with Nagar Nigam officials. A reconnaissance survey was conducted prior to waste characterization to identify the location of sampling points with the objective to address different types of waste generation sources such as residential areas including slum, markets, temple, commercial and institutional area.

\section{Sampling and analysis method}

The total quantity of waste so collected is thoroughly mixed and then reduced by the method of quartering until a physically analyzable sample is obtained. The Physical Characteristics like moisture content, density, percentage of different components, such as, paper, plastic, glass, metal, organic matter, stones, etc. were calculated. The Chemical Characteristics like $\mathrm{pH}$, moisture, density, Nitrogen, Potassium and phosphorus, and the $\mathrm{C} / \mathrm{N}$ ratio were analyzed and represented in the report.

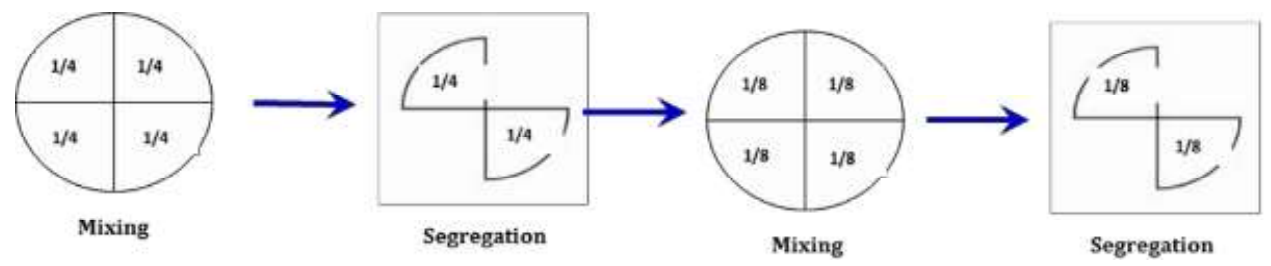

Figure 3: Schematic Diagram of Waste Sampling

All the samples have been analyzed as per the standard code of practice. So,are presentative homogeneous sample has been processed as per IS: 9234. The steps are as follows:

Drying: Oven has been used for drying the sample. Moisture content of the crude sample has been determined during the drying process at $105^{\circ} \mathrm{C}$.

Grinding or Pulverizing before Chemical Analysis: Before grinding, the segregation of various inert materials like glass, ceramics, metals, stones, etc. has been done. The remaining material has been ground and sieved to form a homogenous powder, which has been used for further chemical analysis.

Mixing: Thereafter the processed sample was mixed thoroughly to generate the representative waste sample for analysis for different parameters. The analysis was done as per the respective code of practice. The samples were analyzed for physical composition and chemical parameters such as density, moisture content, organic content, calorific value, and $\mathrm{C} / \mathrm{N}$ ratio. 
Case Study of Primary and Secondary Waste Management Systems in Saharanpur City

Arvind Kumar Arora, Dr. N.C. Mishra, Dr. Mohd. Vasseem

\section{WasteComposition:}

The quantity, as well as its composition (biodegradable, recyclables etc.), are required to arrive at proper technologies for waste processing, viz. Compositing (CC), Biomethanation (BM) etc. The qualitative and quantitative estimate for waste being generated in Saharanpur is carried out and the same is given in subsequent sections.

\section{$\underline{\text { Physical Assessment }}$}

The physical composition of municipal solid waste is normally presented as Organic, Recyclable sand Inert matter. Information and data on the physical composition of solid wastes are important for the selection of equipment and designing the treatment facilities, in assessing the feasibility and in the analysis and design of disposal facilities. Wastecharacteristicsvarynotonly from ULB to ULB but even within the same ULB, as it depends on factors such as the nature of local activities, food habits, cultural traditions, socio-economic factors, climatic conditions

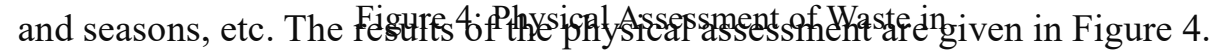

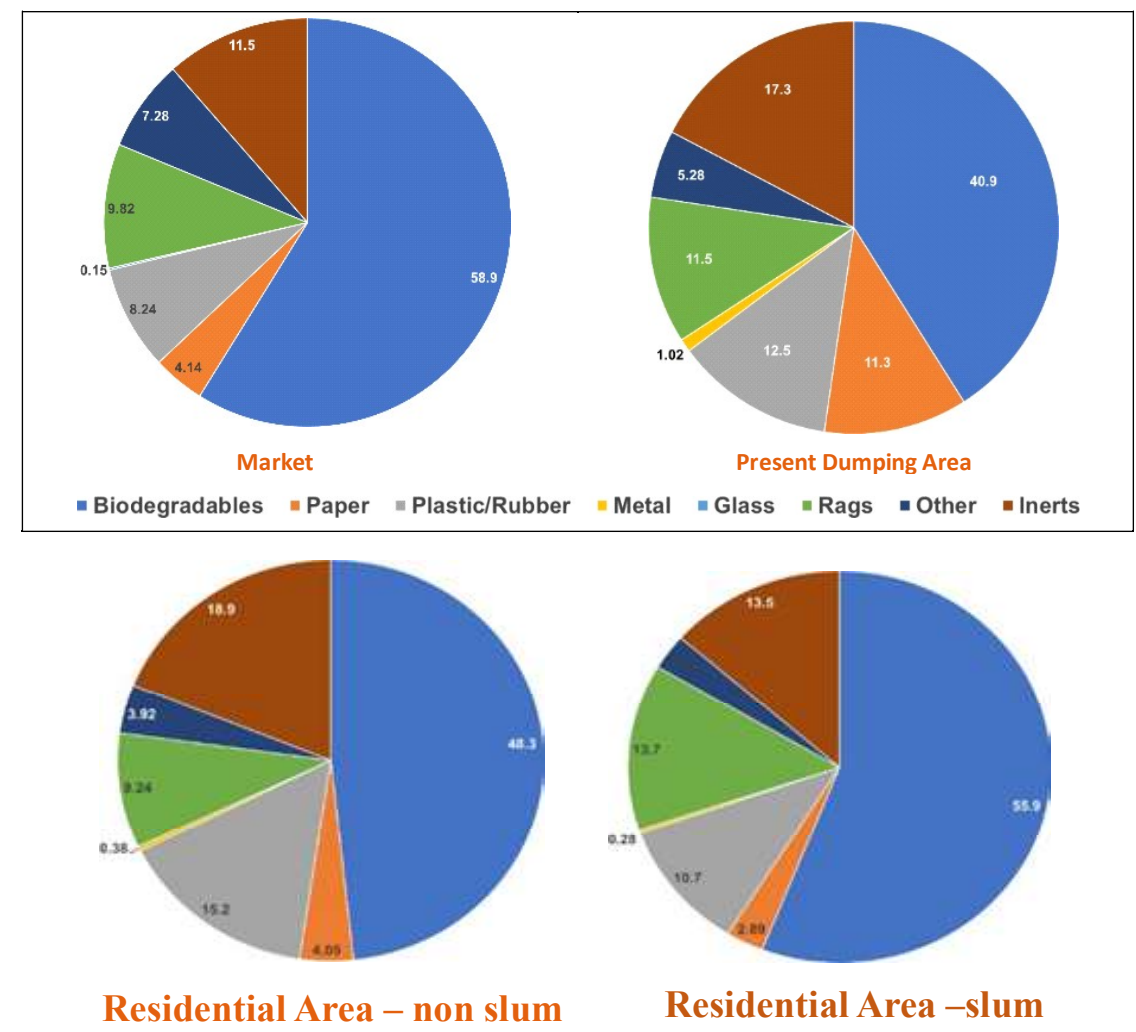




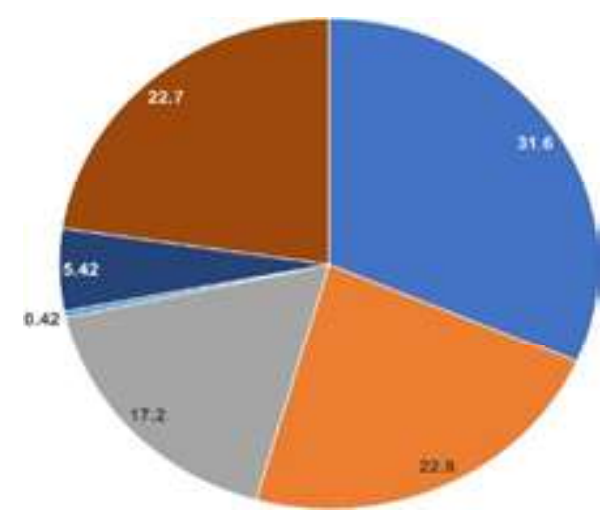

Commercial Area

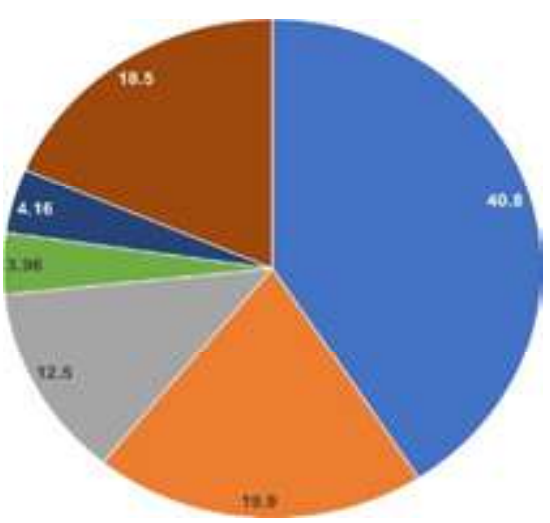

Institutional Area

\section{Other Observations:}

Majority (63 percent) of the households said that the waste is collected daily from their house, about 33 percent throw it openly and 4 percent dispose of the bin near the house. The payment for waste collection is most frequent at the slab of Rs. 10-40. But on the whole, payment varies from Rs. 2-200. Rs. 2 is paid in some slum areas. About 71 percent of the respondents were unaware of the frequency of solid waste collection. Daily cleaning is reported by only 10 percent of HHs.

The highest, frequency of sweeping was reported from HIGs- it was mentioned by about 53 percent that street sweeping is done once in 2-3 days. Of all about 38 percent had reported cleaning in 2-3 days and 33 percent mentioned about dally cleaning. Cleaning once a week was stated by 14 percent HHs. Six percent reported that these are never swept.

Of all 33 percent were willing to pay Rs. 10 more than a quarter wanted to pay Rs. Of all income groups, except the HIG, the majority of the respondents wanted to pay Rs. 10. Majority of the HIGs was willing to pay Rs. 20. 
Case Study of Primary and Secondary Waste Management Systems in Saharanpur City Arvind Kumar Arora, Dr. N.C. Mishra, Dr. Mohd. Vasseem

Table 6: Solid Waste Disposal \%

\begin{tabular}{|l|l|l|l|l|l|}
\hline \multirow{2}{*}{ Disposal } & \multicolumn{4}{l}{ Socio-Economic Group } \\
\cline { 2 - 6 } & HIG & MIG & LIG & Slum & Total \\
\hline Household waste & 80.0 & 74.0 & 60.6 & 57.1 & 63.1 \\
\hline Self-disposed & 10.0 & 1.4 & 4.5 & 3.9 & 4.1 \\
\hline Thrown openly & 10.0 & 23.3 & 34.9 & 39.0 & 32.6 \\
\hline Burn it & 0.0 & 1.4 & 0.0 & 0.0 & 0.2 \\
\hline Total & 4.6 & 16.6 & 61.3 & 17.5 & 100.0 \\
\hline
\end{tabular}

Table 7: Frequency \% of Solid Waste Collection:

\begin{tabular}{|l|l|l|l|l|l|}
\hline \multirow{2}{*}{ Frequency } & \multicolumn{4}{l}{ Socio-Economic Group } \\
\cline { 2 - 6 } & HIG & MIG & LIG & Slum & Total \\
\hline Daily & 6.3 & 16.0 & 9.3 & 7.1 & 10.0 \\
\hline Once in 2-3 days & 12.5 & 4.0 & 8.1 & 2.4 & 6.6 \\
\hline Once in a week & 0.0 & 6.0 & 0.6 & 0.0 & 1.4 \\
\hline Once in 2 weeks & 6.3 & 2.0 & 2.9 & 0.0 & 2.5 \\
\hline No fixed scheduled & 0.0 & 4.0 & 3.5 & 4.8 & 3.6 \\
\hline Never & 0.0 & 0.0 & 6.4 & 7.1 & 5.0 \\
\hline Don't know & 75.0 & 68.0 & 69.2 & 78.6 & 70.7 \\
\hline Total & 5.7 & 17.9 & 61.4 & 15.0 & 100.0 \\
\hline
\end{tabular}

Sources: Primary Citizens survey by IPE

\section{Conclusion:}

Analysis of the waste produced is very crucial to understand the types of infrastructure requirements to dispose of and manage it. Therefore, this paper has been aimed at studying the qualitative and quantitative characteristics of wastes generated in different types of localities in Saharanpur city. As presented above, the composition of wastes is highly variable in each type of locality and hence, requires different kinds of disposal techniques. Besides this, the case study also indicates the frequency of garbage collection and disposal. Since there has not been any such analysis conducted before, this paper is intended to provide the relevant knowledge regarding the composition and characteristics of wastes generated in Saharanpur city in order to help better the waste management system. 
RJPSS Sept. 2020 Vol. XLV No.2, ISSN: (P)0258-1701 (e)2454-3403 Impact Factor: 7.717

\section{References:}

1. Solid waste management in India: options and opportunities: S Gupta, et al, Resources, Conservation and RecyclingVolume 24, Issue 2, November 1998, Pages 137-154.

2. SWA-Tool, Development of a Methodological Tool to Enhance the Precision \& Comparability of Solid Waste Analysis Data (2204), Project Coordinator: iC consulate ZT GmbH, Austria

3. Central Public Health \& Environmental Engineering Organisation (CPHEEO),

4. Primary Citizens survey by IPE, IPE Global Limited (IPE Global). 